\title{
The Chrysochromulina polylepis bloom in the Kattegat (Scandinavia) May-June 1988. Distribution, primary production and nutrient dynamics in the late stage of the bloom
}

\author{
Hanne Kaas ${ }^{1}$, Jacob Larsen ${ }^{2}$, Flemming Møhlenberg ${ }^{1}$, Katherine Richardson ${ }^{3}$ \\ ${ }^{1}$ National Environmental Research Institute, Dept. Marine Ecology and Microbiology, Frederiksborgvej 399, PO Box 358, \\ DK-4000 Roskilde, Denmark \\ ${ }^{2}$ Institut for Sporeplanter, University of Copenhagen, Øster Farimagsgade 2 D, DK-1353 Copenhagen K, Denmark \\ ${ }^{3}$ Danish Institute for Fisheries and Marine Research, Charlottenlund Castle, DK-2920 Charlottenlund, Denmark
}

\begin{abstract}
Chrysochromulina polylepis Manton \& Parke bloomed in the Kattegat and the Skagerrak in May-June 1988 and its distribution, as well as primary production and nitrogen dynamics, were investigated in the Kattegat just prior to the decline of the bloom. The bloom occurred throughout the Kattegat area as a subsurface population associated with the pycnocline. The flagellate was actively photosynthesizing but light-limited in the pycnocline. The primary production of the Chrysochromulina layer represented 50 to $90 \%$ of the total water column production. The specific growth rate of the flagellate was low with doubling times of 4 to $23 \mathrm{~d}$. Ammonium was the major nitrogen source during this late stage of the bloom, accounting for 50 to $85 \%$ of the daily nitrogen uptake. The hourly uptake of ammonium was equal to or exceeded by the ammonium regeneration rate. A minimum primary production of 800 to $1100 \mu \mathrm{g} \mathrm{C}^{-1}$ and a nitrogen demand of 10 to $13 \mu \mathrm{mol} \mathrm{N}{ }^{-1}$ were estimated from the oxygen supersaturation. Profiles of salinity, temperature and oxygen indicate that the nitrogen was supplied by an intrusion of nutrient-rich water in the pycnocline layer early in the bloom. Possible models for the bloom developments are discussed.
\end{abstract}

\section{INTRODUCTION}

In May and early June 1988, an unexpected bloom of the prymnesiophycean flagellate Chrysochromulina polylepis Manton \& Parke was observed in the Kattegat and Skagerrak. Attention was first drawn to the bloom in early May, when caged fish died in the Gulmar Fjord on the eastern shore of the Kattegat (Dahl et al. 1989). In the following weeks, the flagellate was transported northwards by the Baltic Current along the eastern and northern coasts of the Kattegat and the Skagerrak (Dahl et al. 1989, Lindahl \& Dahl 1990). In late May, C. polylepis formed dense subsurface populations associated with the pycnocline in the central and western part of the Kattegat.

The bloom was exceptional because Chrysochromulina polylepis had never previously been reported to form blooms, or to cause severe damage to other flora and fauna (Dahl et al. 1989, Nielsen et al. 1990, Yasomoto et al. 1990). Subsurface chlorophyll maxima as formed by $C$. polylepis in the Kattegat have only occasionally been reported for Scandinavian waters (Edler \& Olsson 1985, Richardson 1985, Nicolaisen \& Christensen 1986).

The present paper describes the distribution and ecophysiology of Chrysochromulina polylepis in the Kattegat in late May and early June. Possible mechanisms involved in the development of the bloom are discussed.

\section{MATERIALS AND METHODS}

Sampling. Data on the Chrysochromulina polylepis bloom were collected during 2 studies conducted in the Kattegat: (I) From 31 May to 7 June, 34 stations 
(including Stns B to F) in the Kattegat, Store Bælt and Øresund were visited during a surveillance cruise with RV 'G. Thorson' (Fig. 1); (II) During the same period, collections were made daily at one station (A) in the southern Kattegat.

At all stations, profiles of salinity, temperature, oxygen, fluorescence and chlorophyll $a$ were measured and Chrysochromulina polylepis cell numbers were counted in samples from 2 or 3 depths. At Stns A to D, primary production (Stns A to D) and nitrogen uptake and remineralization (Stns B \& C) were measured.

Physical and chemical measurements. Methods were described in Nielsen et al. (1990), except that the

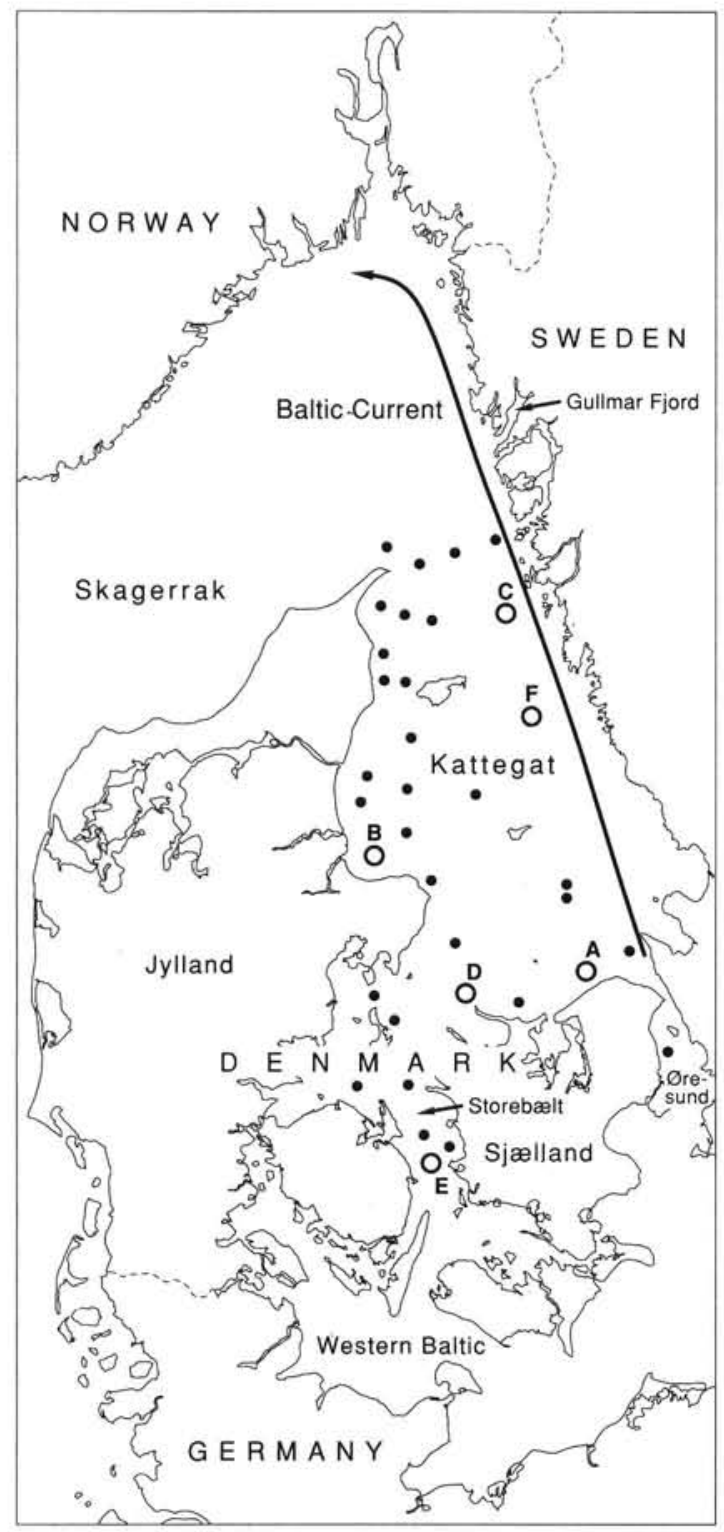

Fig. 1. Sampling stations visited from 31 May through 7 June 1988 during the Chrysochromulina polylepis bloom chlorophyll $a$ is not corrected for phaeopigment. Ammonium concentrations were measured according to Grasshoff (1976).

Identification of bloom organism. Preliminary identification of Chrysochromulina polylepis was made by light microscopy on live samples during the surveillance cruise and on Lugol (acidified) preserved samples from Stn A. The identifications were later confirmed by electron microscopy. Size distribution and particle concentration were determined immediately or within $3 \mathrm{~h}$ after collection using a Coulter Counter TAII fitted with a $140 \mu \mathrm{m}$ orifice tube. For the surveillance stations, the mean volumes of the C. polylepis cells are given as relative values calculated from cell counts and arbitrarily fixed volumes with the volume of the smallest size fraction set as 1 . At Stns A to D, water samples preserved with acidified Lugol's were analysed for species composition, cell numbers, cell volumes and carbon biomass according to the recommendations of the Baltic Marine Environmental Protection Commission - Helsinki Commission (1988).

Primary production. This was measured by the ${ }^{14} \mathrm{C}$ technique. At Stn A, the incubations were carried out in situ and the total ${ }^{14} \mathrm{C}$ fixation including excreted $\mathrm{DO}^{14} \mathrm{C}$ was determined. Samples from 3 depths (above, within and below the Chrysochromulina polylepis layer) received additions of ${ }^{14} \mathrm{CO}_{2}$ in the proportion $1 \mu \mathrm{Ci}{ }^{14} \mathrm{C}$ per $10 \mathrm{ml}$ water. Six subsamples of $9 \mathrm{ml}$ each were incubated in glass scintillation vials mounted in a frame, and the frame placed horizontally at the sampling depth. In addition, samples from the C. polylepis layer ( 3 to 6 replicates) were placed at the surface in a frame mounted with filters that gave a light attenuation similar to that recorded at $2.5 \mathrm{~m}$ depth. At Stns B to D, the incubations were performed in deck incubators under simulated in situ conditions, and only the ${ }^{14} \mathrm{C}$ fixation into particulate matter was determined. The procedure used is described below since the nitrogen and carbon experiments were carried out simultaneously.

Nitrogen uptake $\left(\mathrm{NO}_{3}-\mathrm{N}, \mathrm{NH}_{4}-\mathrm{N}\right)$ and regeneration $\left(\mathrm{NH}_{4}-\mathbf{N}\right)$. These were measured by the ${ }^{15} \mathrm{~N}$-technique. The parameters considered were uptake of ammonium and nitrate (specific and ambient) and ammonium regeneration. Water samples were taken from the fluorescence peak and 2 or 3 additional depths above and below the maximum. Samples for determination of particulate nitrogen (PON) and carbon (POC) were filtered onto precombusted GF/F filters and analysed using a Perkin Elmer Elemental Analyzer 240C. Chlorophyll $a$ and nutrients were determined on parallel samples.

Water samples of 2.51 in polycarbonate bottles received additions of ${ }^{15} \mathrm{~N}$ as ammonium or nitrate at 2 concentrations: 0.1 and $1 \mu \mathrm{M}{ }^{15} \mathrm{NH}_{4} \mathrm{Cl}$ (15 to $40 \%$ and 
150 to $400 \%$ of the ambient concentration) and 0.2 and $5 \mu \mathrm{M} \mathrm{Na}{ }^{15} \mathrm{NO}_{3}$ (71 to 300 and 1785 to $8300 \%$ of ambient concentration). For simultaneous assessment of photosynthetic carbon fixation, $8 \mu \mathrm{Ci} \mathrm{H}_{2}{ }^{14} \mathrm{CO}_{3}$ was added to each bottle.

The bottles were placed in deck incubators screened to simulate the light intensity at the sampling depth. Actual photon flux densities (PFD) were monitored using a Licor cosine Quantum Sensor (400 to $700 \mathrm{~nm}$ ). The temperature in the incubator was kept at in situ level $\pm 1.5^{\circ} \mathrm{C}$ by a flow of sea water.

For the ${ }^{15} \mathrm{~N}$ measurements, 0.51 samples were taken immediately after adding the isotopes and after 2 to $3 \mathrm{~h}$ when terminating the experiments. The water was filtered onto precombusted GF/F filters and dried before further treatment according to Kristiansen \& Paasche (1982). For measurement of ammonium regeneration, the filtrate of the ammonium incubations was treated according to Selmer \& Sörenson (1986). To ensure appropiate nitrogen concentrations for the ${ }^{15} \mathrm{~N}$-analyses, $2 \mu \mathrm{mol}{ }^{14} \mathrm{NH}_{4} \mathrm{Cl}$ was added to the filtrate prior to the reagents. The concentrated indophenol complex was collected on precombusted GF/F filters, which were prepared in the same manner as the filters from the uptake experiments. The ${ }^{15} \mathrm{~N}:{ }^{14} \mathrm{~N}$ ratios of the particulate material and of the water from the ammonium experiments were analysed by microwave emission spectroscopy according to Johansen (1984).

Specific uptake and remineralization rates (V and $\mathrm{R}$ respectively) were calculated as

$$
\begin{aligned}
& \mathrm{V}_{\mathrm{NO}}=\frac{1}{\mathrm{~T}} \times \ln \frac{{ }^{15} \mathrm{~N}_{\mathrm{db}}}{{ }^{15} \mathrm{~N}_{\mathrm{db}}-\left({ }^{15} \mathrm{~N}_{\mathrm{ps}}-{ }^{15} \mathrm{~N}_{\mathrm{pb}}\right)} \\
& \mathrm{R}_{\mathrm{NH}}=\mathrm{S}_{\mathrm{F}} \times \frac{1}{\mathrm{~T}} \times \ln \frac{{ }^{15} \mathrm{~N}_{\mathrm{db}}}{{ }^{15} \mathrm{~N}_{\mathrm{ds}}} \\
& \mathrm{V}_{\mathrm{NH}}=\frac{{ }^{15} \mathrm{~N}_{\mathrm{ps}}-{ }^{15} \mathrm{~N}_{\mathrm{db}}}{\mathrm{S}_{\mathrm{A}}\left({ }^{15} \mathrm{~N}_{\mathrm{ds}}-{ }^{15} \mathrm{~N}_{\mathrm{db}}\right)} \times \mathrm{R}
\end{aligned}
$$

where ${ }^{15} \mathrm{~N}_{\mathrm{d}}=$ excess ${ }^{15} \mathrm{~N} \%$ in the water at the beginning $\left({ }^{15} \mathrm{~N}_{\mathrm{db}}\right)$ and end $\left({ }^{15} \mathrm{~N}_{\mathrm{ds}}\right)$ of the incubation; ${ }^{15} \mathrm{~N}_{\mathrm{p}}=$ the ${ }^{15} \mathrm{~N} \%$ in the particulate material at the beginning $\left({ }^{15} \mathrm{~N}_{\mathrm{pb}}\right)$ and end $\left({ }^{15} \mathrm{~N}_{\mathrm{ps}}\right)$ of the experiment; $\mathrm{T}=$ incubation time (h); $\mathrm{S}_{\mathrm{A}}=$ ambient ammonium concentration; $\mathrm{S}_{\mathrm{F}}=$ ammonium concentration in the filtrate. Uptake rates at ambient nutrient concentrations were estimated assuming that the uptake rate versus nutrient concentration followed Michaelis-Menten kinetics. The absolute uptake rates were calculated as $\mathrm{V} \times \mathrm{PON}$.

For the ${ }^{14} \mathrm{C}$ fixation measurements, 0.51 samples were filtered onto GF/F filters, and the incubations stopped after 2 to $3 \mathrm{~h}$. Scintillation cocktail was added after drying the filters, and the activity and quenching were determined.
Daily uptake rates. Since the irradiance conditions varied between the experiments, the daily uptake rates were estimated to make comparisons. The following assumptions were made: (1) the productive period was $16 \mathrm{~h}$, (2) ammonium uptake was constant during the productive period and $0.6 \times$ the day-rate during the night (own measurements, unpubl.) and (3) nitrate uptake and carbon fixation were proportional to the photon flux density. The daily irradiance was derived from the recorded photon flux densities and the relative irradiance distribution for a 'standard' day in early June.

Assuming a linear relationship between uptake and photon flux density implies that uptake was limited by light. This was justified for carbon fixation by the observed increase in assimilation rates with increasing light level for the pycnocline populations of Chrysochromulina polylepis and by the enhancement of carbon fixation at the $2.5 \mathrm{~m}$ irradiance level (Table 3). For the nitrate uptake, the number of experiments and the PFD spectrum covered were limited and the relationship was not clear.

Carbon specific growth rates. Rates were calculated as $\mathrm{r}=\ln (\mathrm{PC}+$ carbon fixation $) / \mathrm{PC}$ using the daily carbon fixation and PC values (Phytoplankton $\underline{\text { Carbon }}$ biomass) calculated from the number of cells and cell volumes obtained by light microscopy and a volumeto-carbon conversion factor of 0.11 (Baltic Marine Environmental Protection Commission - Helsinki Commission 1988).

\section{RESULTS}

\section{Horizontal distribution}

The horizontal distribution of Chrysochromulina polylepis is shown in Figs. 2 \& 3. The highest cell concentrations and chlorophyll $a$ concentrations were seen along the eastern coast of Jylland. Particularly high biomasses occurred in Gerrild Bay (Stn B) and Sejrø Bay (south of Stn D, unpubl.). The distribution was patchy; north of Sjœlland cell concentrations varied from almost 0 to $17 \times 10^{6}$ cells $1^{-1}$ within a few nautical miles (Fig. 2).

\section{Vertical distribution}

The fluorescence profiles showed a more or less pronounced peak in the upper part of the pycnocline at almost all stations (Fig. 4). The chlorophyll concentra-

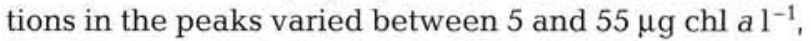
accounting for 55 to $99 \%$ of the total chlorophyll a biomass which was 10 to $300 \mathrm{mg} \mathrm{m}^{-2}$ at the various stations. 
Microscopic examination confirmed that Chrysochromulina polylepis was the dominant species of the subsurface maximum at all stations, except at Stn C, where an unidentified dinoflagellate constituted ca $20 \%$ of the carbon biomass. The dinoflagellate may be identical to the Gymnodinium-like cells observed by Dahl et al. (1989). In the surface layer, the algal biomass was low and Skeletonema costatum was the most important species.

The vertical distribution of nutrients at Stns A to D is given in Table 1. Concentrations were low in the surface layers - usually below $0.1 \mu \mathrm{M} \mathrm{NO}_{3}, 0.6 \mu \mathrm{M}$ $\mathrm{NH}_{4}, 0.15 \mu \mathrm{M}$ SRP (Soluble Reactive Phosphate) and $2 \mu \mathrm{M} \mathrm{SiO}_{4}$. In the bottom waters, the concentrations were 5 to $15 \mu \mathrm{M} \mathrm{NO}_{3}, 0.2$ to $1.25 \mu \mathrm{M} \mathrm{NH}_{4}, 0.2$ to $1.2 \mu \mathrm{M}$ SRP and 2 to $16 \mu \mathrm{M} \mathrm{SiO}_{4}$. The concentrations in the algal peak depths varied. This variation may be due to different sampling depths relative to the nutricline, and probably also to differences in the initial concentrations and/or the consumptions of nutrients.

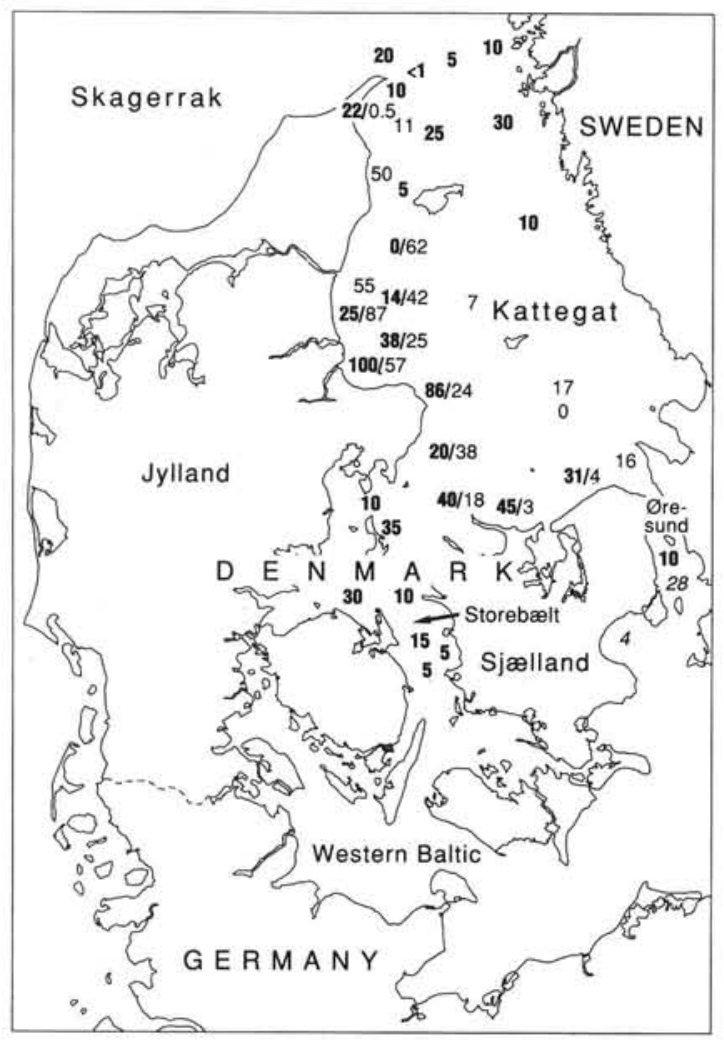

Fig. 2. Chrysochromulina polylepis. Maximum concentrations found from 31 May through 7 June $\left(\times 10^{6}\right.$ cells $\left.1^{-1}\right)$. Several stations were revisited; the numbers in bold type are from 31 May through 3 June, those in lighter type from 6 through 9 June

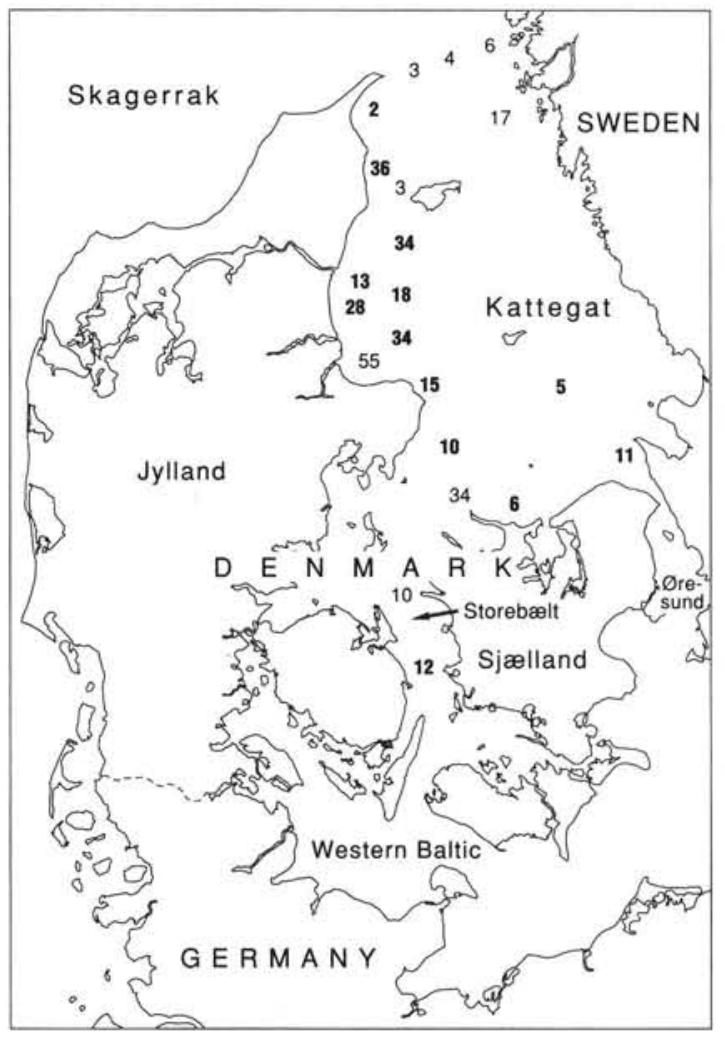

Fig. 3. Maximum chlorophyll a concentrations found at the sampling stations from 31 May through 7 June $\left(\mu \mathrm{g} \mathrm{chl} \mathrm{a} \mathrm{^{-1 } )}\right.$

\section{The Chrysochromulina polylepis cells}

Morphometric data on the Chrysochromulina polylepis cells were obtained from microscopic examination and from the particle distribution analysis (Figs. $5 \& 6$, Table 2). From the microscopic studies, the estimated cell volume was ca $270 \mu \mathrm{m}^{3}$ (cell length ca $10 \mu \mathrm{m}$ ) corresponding to $30 \mathrm{pg} \mathrm{C}$ cell $^{-1}$ (conversion factor 0.11). The Coulter Counter, however, revealed some variation in the cell size with depth, and especially with the time of day.

Circadian variation of cell size was studied at Stn B which was sampled at 3 different times of the day (Fig. 5 and Table 2). It showed that the cells were larger in the evening ( 31 May) than on the following morning. This appeared to be a general pattern at all stations (Fig. 6) indicating that Chrysochromulina polylepis divides predominantly during the dark period, as has also been demonstrated for cultured material (Manton \& Parke 1962).

The variation in cell size with depth at $\mathrm{Stn} B$ is shown in Fig. 5 and Table 2. It appears that the cell size decreased with increasing depths. A similar pattern was observed at the other stations (Table 2). 

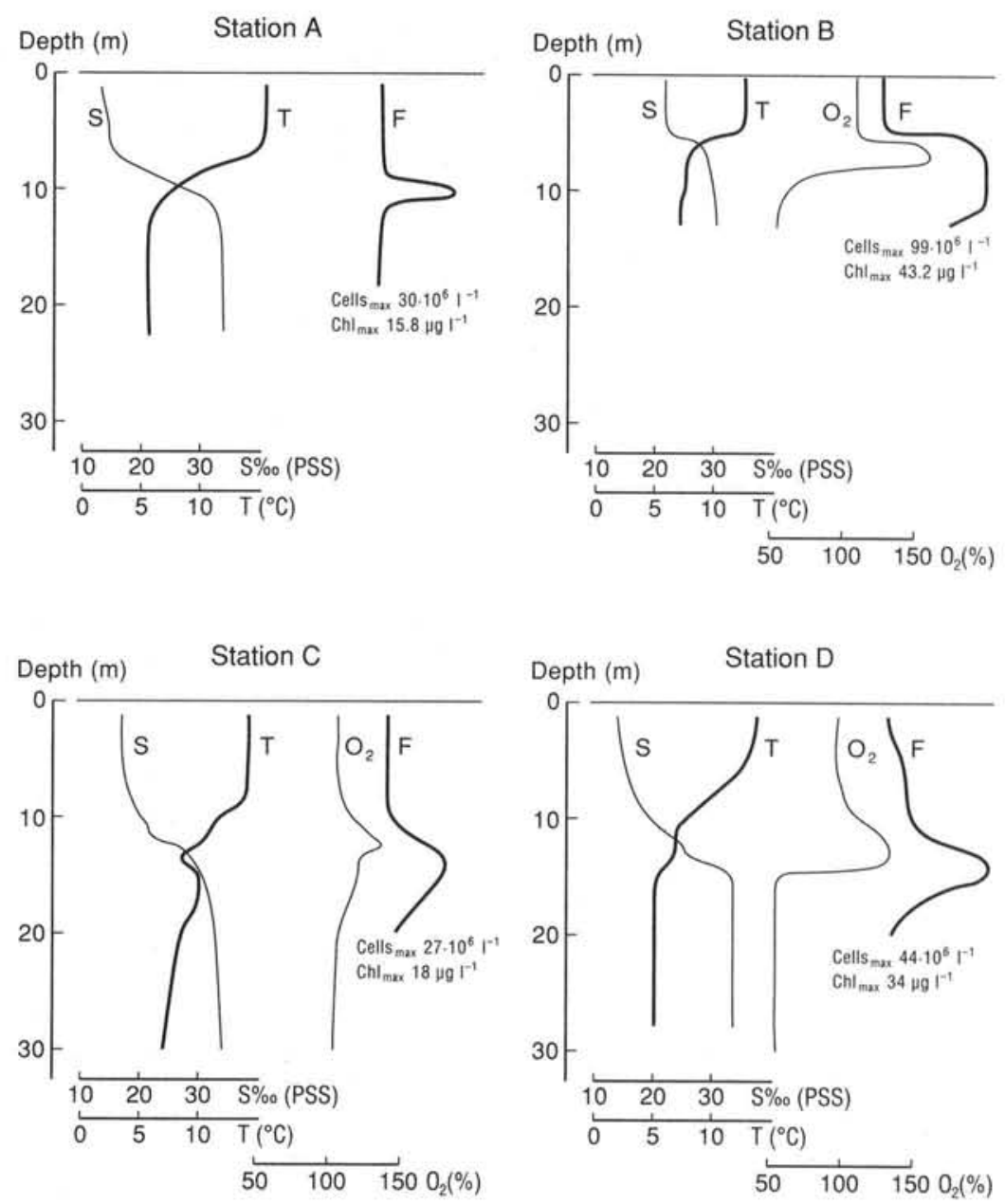

Fig. 4. Salinity (S), temperature (T), oxygen $(\mathrm{O})$ and fluorescence $(\mathrm{F})$ profiles from Stns A to $F$. The maximum cell numbers and chl $a$ values at each station are indicated

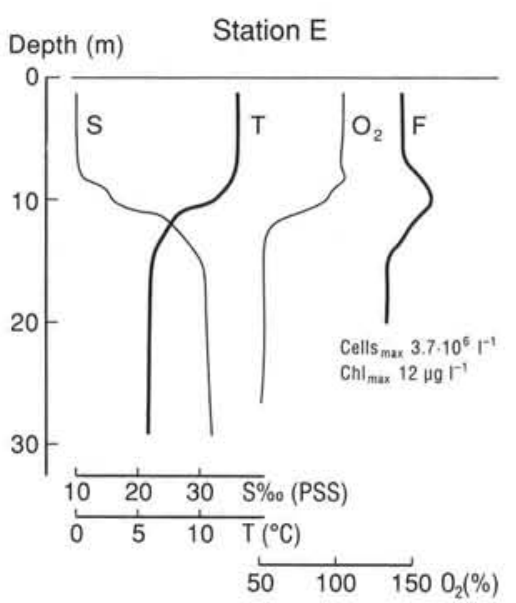

The chlorophyll a content varied from 0.36 to $0.89 \mathrm{pg} \mathrm{cell}{ }^{-1}$ at Stns A to D and the concentration of chlorophyll a per cell increased with depth (Table 2).

The calculated POC and PON cell ${ }^{-1}$ in the natural populations in the central part of Kattegat (at Stns B
\& D) were similar to values found in cultured material (Dahl et al. 1989), suggesting that few other organisms were present in the pycnocline. At Stn C other, especially heterotrophic, organisms were present (Nielsen et al. 1990), which can also be deduced from the high C: chl a ratio (Table 2). 
Table 1. Physical and chemical parameters of Stns A, B, C and D. For comparison, the chlorophyll a data of Stn A are not corrected for phaeopigment. Phaeopigment and the $480 / 665 \mathrm{~nm}$ absorption ratio were only monitored at Stn A. Depths in italics are the Chrysochromulina polylepis depths. Sali.: salinity; Temp.: temperature; AM: ammonium; NI: nitrate; PO: phosphate

\begin{tabular}{|c|c|c|c|c|c|c|c|c|c|c|}
\hline \multirow[t]{2}{*}{ Stn } & \multirow[t]{2}{*}{ Date } & \multirow[t]{2}{*}{$\begin{array}{l}\text { Depth } \\
(\mathrm{m})\end{array}$} & \multirow[t]{2}{*}{$\begin{array}{l}\text { Sali. } \\
(\%)\end{array}$} & \multirow[t]{2}{*}{$\begin{array}{l}\text { Temp. } \\
\left({ }^{\circ} \mathrm{C}\right)\end{array}$} & \multicolumn{3}{|c|}{$\begin{array}{l}\text { Nutrient concentrations } \\
\qquad(\mu \mathrm{M})\end{array}$} & \multirow[t]{2}{*}{$\begin{array}{l}\text { Chlorophyll a } \\
\quad\left(\mu \mathrm{g} \mathrm{1}^{-1}\right)\end{array}$} & \multirow[t]{2}{*}{$\begin{array}{c}\text { Phaeopigment } \\
\left(\mu \mathrm{g} \mathrm{l}^{-1}\right)\end{array}$} & \multirow[t]{2}{*}{$480 / 665$} \\
\hline & & & & & $\mathrm{AM}$ & NI & $\mathrm{PO}$ & & & \\
\hline \multirow[t]{9}{*}{ A } & 30 May & 2.5 & 13.3 & 14.6 & 0.33 & 0 & 0.12 & 0.4 & 0.4 & 1.6 \\
\hline & & 10.0 & 23.6 & 7.6 & 0.43 & 4.2 & 0.66 & 15.4 & 8.3 & 2.3 \\
\hline & & 17.5 & 33.2 & 5.2 & 0.96 & 12.2 & 0.49 & 0.3 & 0.4 & 1.3 \\
\hline & 31 May & 2.5 & 13.0 & 15.3 & 0.43 & 0.6 & 0.45 & 0.8 & 0.6 & 1.5 \\
\hline & & 10.0 & 26.5 & 7.8 & 0.07 & 2.5 & 0.69 & 15.8 & 6.4 & 2.3 \\
\hline & & 17.5 & 33.5 & 5.4 & 0.75 & 11.2 & 0.82 & 0.9 & 0.4 & 1.8 \\
\hline & 1 Jun & 2.5 & 13.0 & 15.4 & 0.16 & 0 & 0.13 & 0.5 & 0.2 & 1.2 \\
\hline & & 10.0 & 23.3 & 8.8 & 1.24 & 7.9 & 0.67 & 8.9 & 3.0 & 2.3 \\
\hline & & 17.5 & 33.5 & 5.4 & 0.69 & 11.9 & 0.91 & 1.0 & 0.5 & 1.8 \\
\hline \multirow[t]{6}{*}{ B } & 1 Jun & 3.0 & 20.3 & 12.5 & 0.15 & 0.1 & 0.10 & 0.6 & - & - \\
\hline & & 6.5 & 26.2 & 8.1 & 0.50 & 0.1 & 0.15 & 20.8 & - & - \\
\hline & & 8.0 & 27.4 & 7.5 & 0.60 & 0.3 & 0.13 & 43.2 & - & - \\
\hline & 2 Jun & 7.0 & 24.9 & 9.0 & 0.10 & 0.1 & 0.09 & 2.8 & - & - \\
\hline & & 8.5 & 26.1 & 8.7 & 0.25 & 0.1 & 0.08 & 7.6 & - & - \\
\hline & & 10.0 & 27.7 & 8.2 & 0.50 & 0.3 & 0.18 & 32.7 & - & - \\
\hline \multirow[t]{3}{*}{ C } & 2 Jun & 5.0 & 17.0 & 14.3 & 0.05 & 0.1 & 0.15 & 0.9 & - & - \\
\hline & & 11.5 & 21.7 & 11.0 & 0.10 & 0.1 & 0.15 & 6.5 & - & - \\
\hline & & 13.5 & 28.6 & 8.6 & 0.20 & 0.2 & 0.14 & 17.4 & - & - \\
\hline \multirow[t]{4}{*}{ D } & 31 May & 5.0 & 15.0 & 13.1 & - & 0.1 & 0.15 & 1.5 & - & - \\
\hline & & 11.5 & 24.4 & 7.1 & - & 0.6 & 0.15 & 5.1 & - & - \\
\hline & & 13.5 & 28.3 & 6.7 & 1.25 & 1.8 & 0.24 & 33.7 & - & - \\
\hline & & 16.0 & 32.7 & 5.4 & - & 5.0 & 0.46 & 13.8 & - & - \\
\hline
\end{tabular}
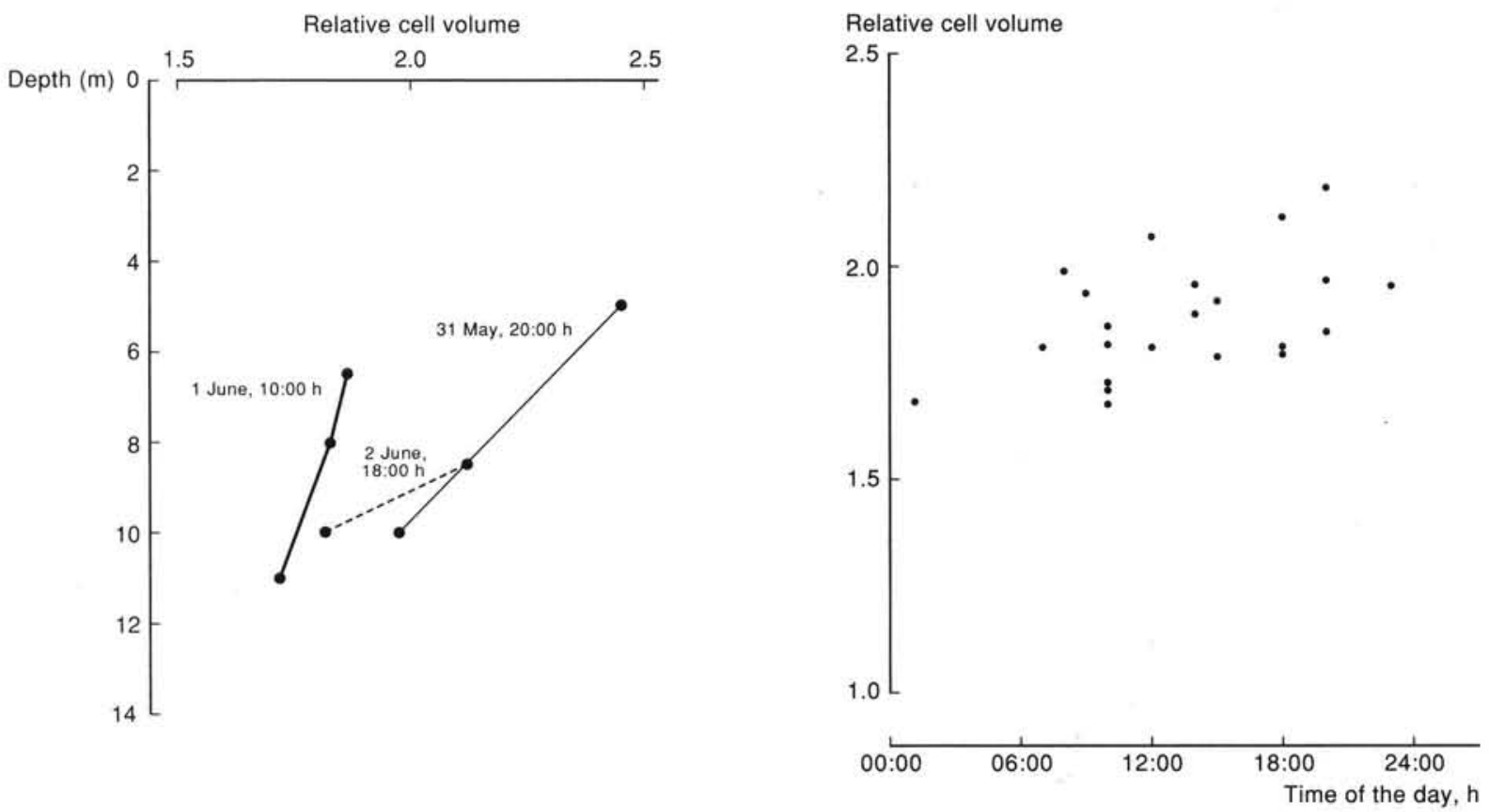

Fig. 5. Chrysochromulina polylepis. Relative volume of cells from Stn B as a function of depth. Data were sampled at 31 May, 20:00 h; 1 June, 10:00 h; and 2 June, 18:00 h
Fig. 6. Chrysochromulina polylepis. Relative volume of cells as a function of sampling time. Data from all stations visited during the RV 'G. Thorson' cruise 
Table 2. Chrysochromulina polylepis cells. Morphometric data and compositional ratios from Stns A to D. Cell volumes are based on Coulter Counter measurements. At Stn A, the volume is estimated from the cell numbers and volumes of the relevant channels. At Stns B to D, the volumes are relative (r.c.v.: relative cell volume, see text)

\begin{tabular}{|c|c|c|c|c|c|c|c|c|c|}
\hline Stn & Date/time & $\begin{array}{l}\text { Depth } \\
\text { (m) }\end{array}$ & $\begin{array}{c}\text { C. polylepis } \\
\text { cells } 1^{-1} \times 10^{6}\end{array}$ & $\begin{array}{l}\text { Cell volume } \\
\left(\mu \mathrm{m}^{3}\right) \text { or r.c.v. }\end{array}$ & $\begin{array}{l}\text { POC cell-1 } \\
\text { (pg) }\end{array}$ & $\begin{array}{l}\text { PON cell }{ }^{-1} \\
(\mathrm{pg})\end{array}$ & $\begin{array}{l}\text { Chl a cell-1 } \\
\text { (pg) }\end{array}$ & $C: N$ & C:chl \\
\hline \multirow[t]{3}{*}{ A } & $\begin{array}{l}30 \text { May } \\
10: 00 \mathrm{~h}\end{array}$ & 10.0 & 28 & 191 & - & - & 0.4 & - & 38 \\
\hline & $\begin{array}{l}31 \text { May } \\
10: 00 \mathrm{~h}\end{array}$ & 10.0 & 30 & 173 & - & - & 0.36 & - & 37 \\
\hline & $\begin{array}{l}1 \mathrm{Jun} \\
10: 00 \mathrm{~h}\end{array}$ & 10.0 & 31 & 160 & - & - & 0.28 & - & 62 \\
\hline \multirow[t]{7}{*}{ B } & 31 May & 5.0 & 16 & 2.46 & - & - & - & - & - \\
\hline & $20: 00 \mathrm{~h}$ & 10.0 & 68 & 1.97 & - & - & - & - & - \\
\hline & 1 Jun & 6.5 & 56 & 1.86 & 34 & 4 & 0.37 & 8.5 & 105 \\
\hline & $10: 00 \mathrm{~h}$ & 8.0 & 95 & 1.82 & 33 & 4 & 0.45 & 8.6 & 73 \\
\hline & & 11.0 & 99 & 1.71 & - & - & - & - & - \\
\hline & 2 Jun & 8.5 & 21 & 2.12 & 53 & 5 & 0.36 & 9.9 & 147 \\
\hline & $18: 00 \mathrm{~h}$ & 10.0 & 75 & 1.81 & 30 & 4 & 0.45 & 8.1 & 78 \\
\hline \multirow[t]{2}{*}{ C } & 2 Jun & 11.5 & 12 & 2.11 & 122 & 18 & 0.54 & 6.8 & 226 \\
\hline & $18: 00 \mathrm{~h}$ & 13.5 & 27 & 2.12 & 99 & 15 & 0.64 & 6.7 & 154 \\
\hline \multirow[t]{2}{*}{ D } & 31 May & 11.5 & 12 & 1.92 & - & - & 0.43 & - & - \\
\hline & $13: 00 \mathrm{~h}$ & 13.5 & 44 & 1.92 & 49 & 5 & 0.76 & 10.4 & 64 \\
\hline
\end{tabular}

\section{Primary production}

The primary production (estimated from both in situ and simulated in situ incubations) showed a significant peak in the pycnocline layer indicating that the Chrysochromulina polylepis populations were actively photosynthesizing under the light conditions prevailing at the pycnocline. Table 3 shows the primary production and assimilation rates at Stns A to D. The assimilation rates were slightly larger at Stn A than at the other Kattegat stations, perhaps due to the varying light conditions encountered during the experiments. Also, the ${ }^{14} \mathrm{CO}_{2}$ fixation is most likely underestimated at Stns B to D because, with the filtration method employed, the ${ }^{14} \mathrm{C}$ exudates were not measured, and in addition the method may easily rupture the very fragile C. polylepis cells. Different physiological conditions of the populations may also have influenced the ${ }^{14} \mathrm{CO}_{2}$ fixation rates.

The production of pycnocline samples incubated at $2.5 \mathrm{~m}$ depth suggests that Chrysochromulina polylepis was light-limited at the pycnocline (Table 3; Stns A \& D). The photosynthetic rates were increased by a factor of 2 to 4 when the light climate was changed from that observed at the pycnocline to that found at the $2.5 \mathrm{~m}$ depth.

Specific growth rates are shown in Table 3. The doubling times were 4 to $23 \mathrm{~d}$.

\section{Nitrogen dynamics}

The results of the simultaneous experiments on nitrogen dynamics and carbon fixation at Stns B \& C are shown in Tables 3 to 5 . With the exception of $\mathrm{Stn} \mathrm{C} / 11.5 \mathrm{~m}$, the daily $\mathrm{C}$ to $\mathrm{N}$ uptake ratios in the Chrysochromulina polylepis layer varied about the Redfield ratio (Table 5).

The importance of nitrate increased with depth (Tables 4 \& 5). The uptake of nitrate constituted 15 to $46 \%$ of the total daily nitrogen uptake in the Chrysochromulina polylepis layer and about $20 \%$ in the surface layers (Table 5).

Ammonium was therefore important for the nitrogen nutrition in the Chrysochromulina polylepis layer as well as at the surface. The consumption of ammonium was exceeded by the ammonium production in the pycnocline layer (Table 4).

\section{DISCUSSION}

In Danish waters, the Chrysochromulina polylepis bloom extended from the brackish western Baltic to the saline North Sea (Dahl et al. 1989, Horstmann \& Jochem 1990). Except in the Baltic Current, the flagellate was associated with the pycnocline (Horstmann \& Jochem 1990, Lindahl \& Dahl 1990). 
Table 3. Primary production, assimilation rates and carbon-specific growth rates at Stns A to D. Depths in italics are the Chrysochromulina polylepis depths. Pot. prod.: potential production; PFD: photon flux densities. The incubations at Stns B to D were performed under simulated in situ conditions

\begin{tabular}{|c|c|c|c|c|c|c|c|c|}
\hline Stn & Date & $\begin{array}{l}\text { Depth } \\
(\mathrm{m})\end{array}$ & $\begin{array}{c}\text { PFD } \\
\left(\mu \mathrm{E} \mathrm{m}^{-2} \mathrm{~s}^{-1}\right)\end{array}$ & $\begin{array}{c}C \text { fixed } \\
\left(\mu \mathrm{g}^{-1} \mathrm{~h}^{-1}\right)\end{array}$ & $\begin{array}{c}\text { Pot. prod. } \\
\text { at } 2.5 \mathrm{~m} \\
\left(\mu \mathrm{g} \mathrm{C}^{-1} \mathrm{~h}^{-1}\right)\end{array}$ & $\begin{array}{r}\text { Assim } \\
(\mu \mathrm{g} C[\mu \\
\text { In situ }\end{array}$ & $\begin{array}{l}\text { n rate } \\
a^{-1} \mathrm{~h}^{-1} \text { ) } \\
\text { Potential }\end{array}$ & $\begin{array}{c}\text { Carbon specific } \\
\text { growth rate } \\
\left(\mathrm{d}^{-1}\right)\end{array}$ \\
\hline \multirow[t]{3}{*}{ A } & 30 May & $\begin{array}{r}2.5 \\
10.0\end{array}$ & $\begin{array}{r}1177 \\
130\end{array}$ & $\begin{array}{r}2.1 \\
14.5\end{array}$ & - & $\begin{array}{l}5.0 \\
1.3\end{array}$ & - & $\overline{0.17}$ \\
\hline & 31 May & $\begin{array}{r}2.5 \\
10.0\end{array}$ & $\begin{array}{r}575 \\
80\end{array}$ & $\begin{array}{r}2.6 \\
12.4\end{array}$ & $\overline{47.0}$ & $\begin{array}{l}2.6 \\
1.1\end{array}$ & 3.0 & $\overline{0.12}$ \\
\hline & 1 Jun & $\begin{array}{r}2.5 \\
10.0\end{array}$ & $\begin{array}{l}757 \\
100\end{array}$ & $\begin{array}{r}0.6 \\
12.4\end{array}$ & $\frac{-}{60.0}$ & $\begin{array}{l}0.3 \\
1.9\end{array}$ & $\frac{-}{6.7}$ & $\overline{0.15}$ \\
\hline \multirow[t]{2}{*}{ B } & 1 Jun & $\begin{array}{l}3.0 \\
6.5 \\
8.0\end{array}$ & $\begin{array}{r}586 \\
113 \\
24\end{array}$ & $\begin{array}{r}1.4 \\
14.9 \\
18.7\end{array}$ & $\begin{array}{l}- \\
- \\
-\end{array}$ & $\begin{array}{l}2.3 \\
0.7 \\
0.4\end{array}$ & $\begin{array}{l}- \\
- \\
-\end{array}$ & $\begin{array}{l}- \\
0.07 \\
0.08\end{array}$ \\
\hline & 2 Jun & $\begin{array}{r}7.0 \\
8.5 \\
10.0\end{array}$ & $\begin{array}{r}37 \\
15 \\
4\end{array}$ & $\begin{array}{l}1.0 \\
2.7 \\
1.8\end{array}$ & $\begin{array}{l}- \\
- \\
-\end{array}$ & $\begin{array}{l}0.4 \\
0.4 \\
0.1\end{array}$ & $\begin{array}{l}- \\
- \\
-\end{array}$ & $\begin{array}{l}- \\
0.19 \\
0.03\end{array}$ \\
\hline C & 2 Jun & $\begin{array}{r}5.0 \\
11.5 \\
13.5\end{array}$ & $\begin{array}{r}113 \\
43 \\
9\end{array}$ & $\begin{array}{l}0.7 \\
1.6 \\
4.7\end{array}$ & $\begin{array}{l}- \\
- \\
-\end{array}$ & $\begin{array}{l}0.7 \\
0.3 \\
0.3\end{array}$ & $\begin{array}{l}- \\
- \\
-\end{array}$ & $\begin{array}{l}- \\
0.07 \\
0.09\end{array}$ \\
\hline D & 31 May & $\begin{array}{c}13.5 \\
-\end{array}$ & $\begin{array}{r}6 \\
28\end{array}$ & $\begin{array}{l}1.9 \\
-\end{array}$ & $\overline{4.3}$ & $\begin{array}{c}0.1 \\
-\end{array}$ & $\overline{-}$ & 0.05 \\
\hline
\end{tabular}

The meteorological and hydrographic conditions in May, with a stabilized water column and high solar radiation (Rosenørn 1989, Schrøder 1989), and in addition a low algal biomass in the surface water, were ideal for the development of a subsurface bloom (Banse 1987). Chrysochromulina polylepis was not observed during the first week of May in the Kattegat (data from monitoring program, unpubl.), so the bloom must have developed during the last $3 \mathrm{wk}$ of the month. This is conceivable assuming a generation time of $1.2 \mathrm{~d}$ which was observed by Lindahl \& Dahl (1990) in the developing bloom, and an initial population of only 1000 cells $1^{-1}$. Under these circumstances, it would require $18 \mathrm{~d}$ to reach a cell concentration of $30 \times 10^{6} 1^{-1}$ (assuming no grazing; Nielsen et al.
1990) - a number encountered at many places in the Kattegat.

The generation times observed during our cruise at the end of May ( 4 to $23 \mathrm{~d}$ ) indicate that the bloom was in its late stage of growth. This is also supported by the high phaeopigment concentrations, the high 480/665 $\mathrm{nm}$ absorption ratios (>2; Heath et al. 1990), and presumably by the importance of ammonium as the nitrogen source.

Although Chrysochromulina polylepis was in a late stage of growth, it still constituted the major primary producer in the water column. At Stn A, the C. polylepis layer alone was estimated to contribute at least $50 \%$ of the total water column production. It was assumed here that the productive layer extended

Table 4. Specific and absolute hourly nitrate and ammonium uptake at Stns B \& C. The $f$-ratio is the nitrate uptake in relation to the total nitrogen $\left(\mathrm{NH}_{4}+\mathrm{NO}_{3}\right)$ uptake. Specific carbon fixation rates (assimilation rates) are given in Table 3 . Depths in italics are the Chrysochromulina polylepis depths. A/R: absolute uptake/remineralization of ammonium

\begin{tabular}{|c|c|c|c|c|c|c|c|c|c|c|}
\hline \multirow[t]{2}{*}{ Stn } & \multirow[t]{2}{*}{ Date } & \multirow[t]{2}{*}{$\begin{array}{l}\text { Depth } \\
(\mathrm{m})\end{array}$} & \multicolumn{3}{|c|}{$\begin{array}{c}\text { Specific uptake } \\
\left(\mu \mathrm{g} \mathrm{N}[\mu \mathrm{g} \mathrm{chl} a]^{-1} \mathrm{~h}^{-1}\right)\end{array}$} & \multicolumn{2}{|c|}{$\begin{array}{l}\text { Absolute uptake } \\
\left(\mu \mathrm{g} \mathrm{N}^{-1} \mathrm{~h}^{-1}\right)\end{array}$} & \multirow[t]{2}{*}{$\begin{array}{c}f \text {-ratio } \\
(\%)\end{array}$} & \multirow{2}{*}{ 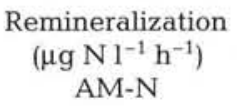 } & \multirow[t]{2}{*}{$\mathrm{A} / \mathrm{R}$} \\
\hline & & & NI-N & AM-N & $C: N$ & NI-N & AM-N & & & \\
\hline \multirow[t]{3}{*}{ B } & 1 Jun & 3.0 & 0.1456 & 0.3483 & 4.7 & 0.0874 & 0.209 & 29 & 0.252 & 0.8 \\
\hline & & 6.5 & 0.0121 & 0.0298 & 17 & 0.2511 & 0.619 & 29 & 1.17 & 0.5 \\
\hline & & 8.0 & 0.0246 & 0.0161 & 9.8 & 1.0614 & 0.695 & 60 & 1.12 & 0.6 \\
\hline \multirow[t]{3}{*}{$\mathrm{C}$} & 2 Jun & 5.0 & 0.0537 & 0.2022 & 2.7 & 0.0483 & 0.182 & 21 & 0.364 & 0.5 \\
\hline & & 11.5 & 0.0103 & 0.0748 & 3.5 & 0.0670 & 0.486 & 12 & 0.672 & 0.7 \\
\hline & & 13.5 & 0.0084 & 0.0161 & 12 & 0.1456 & 0.280 & 34 & 0.924 & 0.3 \\
\hline
\end{tabular}


Table 5. Daily nitrogen uptake and carbon fixation at Stns B \& C. The $f$-ratio is the nitrate uptake in relation to the total nitrogen uptake. At Stn A, the daily carbon fixation in the Chrysochromulina polylepis layer (10.0 m) was: 30 May, 154; 31 May, 113; and 1 June, $146 \mu \mathrm{g} \mathrm{Cl}^{-1} \mathrm{~d}^{-1}$, respectively. Depths in italics are the C. polylepis depths

\begin{tabular}{|c|c|c|c|c|c|c|}
\hline Stn & Date & $\begin{array}{l}\text { Depth } \\
(\mathrm{m})\end{array}$ & $\begin{array}{l}\text { Daily nitrogen uptake } \\
\qquad\left(\mu \mathrm{g} \mathrm{N}^{-1} \mathrm{~d}^{-1}\right)\end{array}$ & $\begin{array}{c}\text { f-ratio } \\
(\%)\end{array}$ & $\begin{array}{l}\text { Daily carbon fixation } \\
\qquad\left(\mu \mathrm{g} \mathrm{C} 1^{-1} \mathrm{~d}^{-1}\right)\end{array}$ & $\begin{array}{l}\text { Daily } \mathrm{C}: \mathrm{N} \\
\text { uptake ratio }\end{array}$ \\
\hline \multirow[t]{3}{*}{ B } & 1 Jun & 3.0 & 4.3 & 21 & 20 & 4.7 \\
\hline & & 6.5 & 12 & 27 & 127 & 10 \\
\hline & & 8.0 & 18 & 46 & 141 & 7.8 \\
\hline \multirow[t]{3}{*}{ C } & 2 Jun & 5.0 & 2.9 & 18 & 21 & 7.2 \\
\hline & & 11.5 & 11 & 15 & 36 & 3.2 \\
\hline & & 13.5 & 11 & 27 & 77 & 7.3 \\
\hline
\end{tabular}

down to and included the bloom, and that the phytoplankton in the surface layer (above $9 \mathrm{~m}$ ) was lightsaturated and had the same photosynthetic characteristics as found at $2.5 \mathrm{~m}$. It is likely that photosynthesis is not light-saturated in the entire surface layer, in which case the contribution of $C$. polylepis to the primary production is underestimated. At Stns B \& C, the $C$. polylepis layer was estimated to contribute about $90 \%$ and $80 \%$ respectively of the total water column production.

In high concentrations, ammonium inhibits nitrate uptake (Paasche 1988), and this may explain why ammonium was observed to be the principal nitrogen source. However, the regeneration of ammonium is difficult to explain. The abundance of potential ammonium producers was low in the southern Kattegat (Stns A \& B), and the activity of microheterotrophs was inhibited by the algal bloom (Nielsen et al. 1990). Therefore, it is tempting to suggest that the aging C. polylepis bloom itself was the source of ammonium, although Garber (1984) found that autolytic Nremineralization does not usually occur during decomposition of phytoplankton.

Subsurface growth of algae is usually supported by entrainment and eddy diffusion of nutrients from the bottom waters (Banse 1987, Harrison 1990), but this was hardly the situation for the Kattegat bloom. Chrysochromulina polylepis grew in a water layer which represented an intrusion of intermediate density waters in the pycnocline. This is indicated by the salinity and temperature profiles (Fig 4 ; Stns C to F), and salinity vs temperature plots (not shown). From the supersaturation of oxygen in the intrusion layer, a minimum production of 3 to $4 \mathrm{~g} \mathrm{C} \mathrm{m}^{-2}$, corresponding to a nitrogen demand of about $50 \mathrm{mmol} \mathrm{m}^{-2}$, was estimated (Fig. 7). This nitrogen demand would require an entrainment of about $5 \mathrm{~m}$ of bottom water to the pycnocline layer. Considering the meteorological conditions, and the persistence of the intrusion layer together with the supersaturation of oxygen, an entrainment of this size is unlikely. More likely, the nutrients were introduced into the pycnocline with the intrusion, e.g. by a density-driven spreading of nutrient-rich waters from the northern Kattegat (Schrøder 1989).

The history of the Chrysochromulina polylepis development in the Kattegat proper is unknown since no observations were made between early May, when C. polylepis was very rare, and late May, when the bloom was declining. Two models of the development of the bloom are proposed: (1) the development was initiated in the surface waters and, when the nutrients were exhausted here, the flagellate concentrated in the pycnocline layer, where favourable growth conditions supported further growth, or (2) the development was entirely associated with the pycnocline.

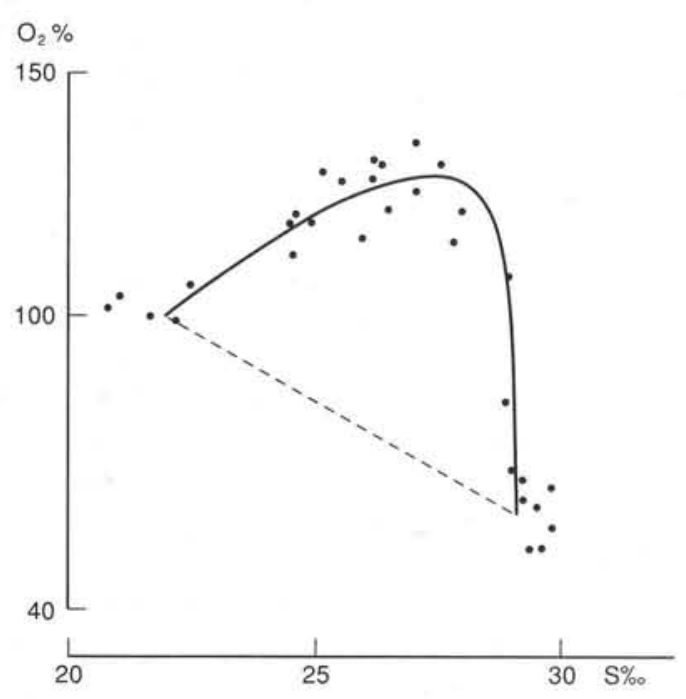

Fig. 7. Salinity-oxygen diagram from Stn B. The minimum $\mathrm{O}_{2}$ production in the Chrysochromulina polylepis layer is estimated by integration under the salinity $-\mathrm{O}_{2}$ curve. The oxygen production is then converted into primary production assuming that $1 \mathrm{ml} \mathrm{O}_{2}$ is produced per $0.4 \mathrm{mg} \mathrm{C}$ fixed. To calculate the nitrogen demand the Redfield ratio $\mathrm{C}: \mathrm{N}=6: 1$ is used. A minimum primary production of $800 \mu \mathrm{g} \mathrm{C} 1^{-1}$ (Stn A) and $1100 \mu \mathrm{g} \mathrm{C} 1^{-1}$ (Stn B) and a nitrogen demand of 10 and $13 \mu \mathrm{mol}^{-1}$ respectively is estimated 
In favour of the first type of development are the observations from the Gulmar Fjord (see Fig. 1), where maximum growth of Chrysochromulina polylepis took place in the nutrient-rich surface layers. Only in the later stages of the bloom, the flagellate concentrated in the deeper water and, eventually, at the pycnocline (Lindahl \& Dahl 1990). Subsurface accumulation of algae sinking out of the nutrient-exhausted surface waters has been demonstrated previously by Steele \& Yentsch (1960), Eppley et al. (1967) and Venrick et al. (1973). In the Kattegat, however, the surface layers were depleted of nutrients in early May (data from monitoring cruise, unpubl.). Easterly winds in midMay (Rosenørn 1989, Schrøder 1989) may have spread Baltic Current water over the surface of the rest of Kattegat, thus inoculating both C. polylepis cells and nutrients. It is unlikely, however, that nutrients from the Baltic Current could have sustained significant growth of C. polylepis in the surface of the Kattegat, which may explain the accumulation of cells and subsequent development of the bloom in the pycnocline.

The second type of development implies that subsurface populations in the Skagerrak were spread to the Baltic Current surface waters by upwelling along the Swedish coast. This is quite probable as easterly winds prevailed in the beginning of May (Rosenørn 1989). Such spreading patterns have previously been suggested in this area for Gyrodinium aureolum (Dahl et al.1982, Lindahl 1983, Richardson \& Kullenberg 1987). It is unknown, however, if Chrysochromulina polylepis was present in the subsurface populations in the frontal area in the Skagerrak in late April and early May.

The Chrysochromulina polylepis bloom was an 'exceptional bloom' according to the definition of Paerl (1988). It formed an almost unialgal population discolouring the waters and had toxic effects on other flora and fauna. The formation of subsurface algal maxima in the pycnocline may be a frequent feature in the Kattegat. Recent studies have indicated that algal growth in the pycnocline is common in the summer and autumn (Richardson \& Christoffersen 1991, Nielsen pers. comm.), and that the biomass and production observed during the C. polylepis bloom were not unusual (Nicholaisen \& Christensen 1986, Richardson \& Christoffersen 1991). The C. polylepis bloom demonstrated that advective processes resulting in intrusion of 'new' water in the pycnocline layer may be an important mechanism in pycnocline algal development in the Kattegat.

Acknowledgements. We acknowledge grants from the Danish Environmental Protection Agency. Hanne Ferdinand, Gitte Jørgensen, Peter Kofoed, Ellen Bagge and the crew of RV 'G. Thorson' are thanked for technical assistance.

\section{LITERATURE CITED}

Baltic Marine Environment Protection Commission - Helsinki Commission (1988). Guideline for the Baltic monitoring programme for the third stage; part D. Biological determinants. Baltic Sea Environmental Proceedings No. 27D

Banse, K. (1987). Clouds, deep chlorophyll maxima and the nutrient supply to mixed layer of stratified water bodies. J. Plankton Res. 9: 1031-1036

Dahl, E., Danielssen, D. S., Bøhle, B. (1982). Massforekomst av Gyrodinium aureolum Hulburt og fiskedødelighet langs sydkysten av Norge i september-oktober 1981. Flødevigen Rapportserie 4: 1-15

Dahl, E., Lindahl, O., Paasche, E., Throndsen, J. (1989). The Chrysochromulina polylepis bloom in Scandinavian waters during spring 1988. In: Cosper, E. M., Bricelj, V. M., Carpenter, E. J. (eds.) A novel phytoplankton bloom. Causes and impacts of recurrent brown tides. Coastal and Estuarine Studies, Vol. 35. Springer-Verlag, New York, p. 383-405

Edler, L., Olsson, P. (1985). Observations on diel migration of Ceratium furca and Prorocentrum micans in a stratified bay on the Swedish west coast. In: Anderson, D. M., White, A. W., Baden, D. G. (eds.) Toxic dinoflagellates. Elsevier, New York, p. 195-200

Eppley, R. W., Holmes, R. W., Strickland, J. D. H. (1967). Sinking rates of marine phytoplankton measured with a fluorometer. J. exp. mar. Biol. Ecol. 1: 191-208

Garber, J. H. (1984). Laboratory study of nitrogen and phosphorus remineralization during the decomposition of coastal plankton and seston. Estuar. coast. Shelf Sci. 18: $685-702$

Grasshoff, K. (1976). Methods of seawater analysis. Verlag Chemie, Weinheim

Harrison, W. G. (1990). Nitrogen utilization in chlorophyll and primary productivity maximum layers: an analysis based on the f-ratio. Mar. Ecol. Prog. Ser. 60: 85-90

Heath, M., Richardson, K., Kiørboe, T. (1990). Optical assessment of phytoplankton nutrient depletion. J. Plankton Res. 12: $381-396$

Horstmann, U., Jochem, F. (1990). Report of the activities and first results of the investigations on the Chrysochromulina bloom in FRG. In: Lancelot, C., Billen, G., Barth, H. (eds.) Eutrophication and algal blooms in the North Sea coastal zones, the Baltic and adjacent areas: prediction and assessment of preventive actions. Commission of the European Communities, Brussels EUR 12190en - Water Pollution Research Report 12

Johansen, H. S. (1984). Improved optical analysis of traces depleted or slightly enriched in ${ }^{15} \mathrm{~N}$. Int. J, appl. Radiat. Isot. 35: 1039-1043

Kristiansen, S., Paasche, E. (1982). Preparation of $\mathrm{N}^{15}$-labeled phytoplankton samples for optical emission spectrometry. Limnol. Oceanogr. 27: 373-375

Lindahl, O. (1983). On the development of a Gyrodinium aureolum occurrence on the Swedish west coast in 1982. Mar. Biol. 77: 143-150

Lindahl, O. Dahl, E. (1990). On the development of the Chrysochromulina polylepis bloom in the Skagerrak in May-June 1988. In: Graneli, E., Sundstrøm, B., Edler, E., Anderson, D. M. (eds.) Toxic marine phytoplankton. Elsevier, London, p. 189-194

Manton, I., Parke, M. (1962). Preliminary observations on scales and their mode of origin in Chrysochromulina polylepis sp. nov. J. mar. biol. Ass. U.K. 42: 565-578

Nicolaisen, W., Christensen, H. (1986). Pelagic turnover and transport to the bottom of particulate organic material in the northern Øresund. Ophelia 26: 317-332 
Nielsen, T. G., Kiørboe, T., Bjørnsen, P. K. (1990). Effects of a Chrysochromulina polylepis subsurface bloom on the planktonic community. Mar. Ecol. Prog. Ser. 62: 21-35

Paasche, E. (1988). Pelagic primary production in nearshore waters. In: Blackburn, T. H., Sørensen, J. (eds.) Nitrogen cycling in coastal marine environments. John Wiley \& Sons, New York, p. 33-37

Paerl, H. (1988). Nuisance phytoplankton blooms in coastal, estuarine and inland waters. Limnol. Oceanogr. 33: 823-847

Richardson, K. (1985). Plankton distribution and activity in the North Sea/Skagerrak-Kattegat frontal area in April 1984. Mar. Ecol. Prog. Ser. 26: 233-244

Richardson, K., Christoffersen, A. (1991). Seasonal distribution and production of phytoplankton in the southern Kattegat. Mar. Ecol. Prog. Ser. 78: 217-227

Richardson, K., Kullenberg, G. (1987). Physical and biological interactions leading to plankton blooms: a review of Gyrodinium aureolum blooms in Scandinavian waters. Rapp. P.-v. Réun. Cons. int. Explor. Mer 187: 19-26

Rosenørn, S. (1989). Physical conditions compared with normal conditions. Meteorology. In: Barth, H., Nielsen, A. (eds.) The occurrence of Chrysochromulina polylepis in the Skagerrak and Kattegat in May/June 1988: An analysis of extent, effects and causes. Commission of the

This article was submitted to the editor
European Communities, Brussels EUR 12069en - Water Pollution Research Report 10

Schrøder, H. (1989). Physical conditions compared with normal conditions. Oceanography. In: Barth, H., Nielsen, A. (eds.) The occurrence of Chrysochromulina polylepis in the Skagerrak and Kattegat in May/June 1988: an analysis of extent, effects and causes. Commission of the European Communities, Brussels EUR 12069en - Water Pollution Research Report 10

Selmer, J.-S., Sörensson, F. (1986). New procedure for extraction of ammonium from natural waters for ${ }^{15} \mathrm{~N}$ isotopic ratio determinations. Appl. environ. Microbiol. 52: $577-579$

Steele, J. H., Yentsch, C. S. (1960). The vertical distribution of chlorophyll. J. mar. biol. Ass. U.K. 39: 217-226

Venrick, E. L., McGowan, J. A., Mantyla, A. W. (1973). Deep maxima of photosynthetic chlorophyll in the Pacific Ocean. Fish. Bull. U.S. 71: 41-52

Yasomoto, T., Underdal, B., Aune, T., Hormazabal, V., Skulberg, O. M., Oshima, Y. (1990). Screening for hemolytic and ichtyotoxic components of Chrysochromulina polylepis and Gyrodinium aureolum from Norwegian coastal waters. In: Graneli, E., Sundstrøm, B., Edler, E., Anderson, D. M. (1990). Toxic marine phytoplankton. Elsevier, London, p. 436-440

Manuscript first received: June 27, 1991

Revised version accepted: December 2, 1991 